\title{
Development history and prospect of remote sensing technology in coal geology of China
}

\author{
Kelong Tan ${ }^{1} \cdot$ Junwei Qiao ${ }^{2,3}$
}

Received: 2 July 2019/Revised: 14 January 2020/Accepted: 10 April 2020/Published online: 8 May 2020

(C) The Author(s) 2020

\begin{abstract}
Coal remote sensing technology was founded in the period of coal resources survey after the founding of People's Republic of China. Aerophoto Grammetry \& Remote Sensing Bureau of China National Administration of Coal Geology was established, specializing in the application and promotion of coal remote sensing technology. With the rapid development of coal geological exploration in China, coal remote sensing technology has evolved from coal geology based survey to comprehensive survey that factors in resources, environment, ecology and so on. This paper summarizes the general situation, theories, development process, key research and future of remote sensing technology for coal mining in China. Spanning over 50 years, the history of China's coal remote sensing technology can be divided into five stages: aerogeological mapping, coal remote sensing theory experimental research, application research and promotion, architecture planning and productionisation, " $3 \mathrm{~S}$ " technology integration and application. This paper expounds the main technical progress, application fields, major projects and major achievements in various historical periods, and points out that the coal remote sensing has entered a unified development stage of "Aviation, Aerospace and Ground", with a focus on highresolution remote sensing, hyperspectral remote sensing, radar remote sensing, "3S" technology integration and multimeans comprehensive exploration and evaluation. In the future, coal remote sensing technology will develop rapidly in data mass, technology integration, evaluation intelligence, integration application programming, system visualization, etc. Coal remote sensing technology has entered the industrial development from technology application.
\end{abstract}

Keywords Remote sensing $\cdot$ Coal remote sensing $\cdot$ Coal geology $\cdot$ Industrialization

Coal remote sensing technology developed in the period of coal resources survey after the founding of People's

Kelong Tan

tan-k1@163.com

Junwei Qiao

Qiaojunwei@xust.edu.cn

1 General Prospecting Institute of China National Administration of Coal Geology, Beijing 100039, China

2 College of Geology and Environment, Xi' an University of Science and Technology, Xi' an 710054, Shaanxi, China

3 Aerophoto Grammetry and Remote Sensing Bureau, China National Administration of Coal Geology, Xi' an 710100, Shaanxi, China
Republic of China. Due to China's energy resource condition, which is "lack of oil, lack of gas and relatively rich coal", coal constitutes the base of China's energy and mineral resources (Li 2018; Wang 2007). Therefore, coal geological exploration became a critical task to recover and stimulate national economy (China National Administration of Coal Geology 1993). Remote sensing technology has the advantages of more intuition, large amount of minable information and less likely bounded by the ground conditions. It was quickly applied in the coal geological exploration in 1960s. In 1965, Aerophoto Grammetry \& Remote Sensing team of China National Administration of Coal Geology (the predecessor of Aerophoto Grammetry \& Remote Sensing Bureau of China National Administration 
of Coal Geology, ARSC) was formed to drive projects on aerial measurements and applications of remote sensing technology in coal geological exploration, gradually laying out the foundations of theory and application of coal remote sensing in China.

\section{Overview of coal remote sensing technology}

\subsection{General situations}

Every object has different characteristics of absorption, reflection and radiation to electromagnetic wave, which are also affected by time, place, sunlight etc. (Irvin 2002; Wang et al. 2011; Hu and Li 1990; Liu et al. 2005; Zhou 2018). Remote sensing technology can detect and identify a target by sensing the electromagnetic wave, visible light and infrared rays reflected or radiated by the target from a long distance (Nie and Yang 2009; Sun 2013; Yang 1987). In the 1960s, with the development of space technology and electronic computer, a comprehensive sensing technology evolved from aerial photography and manual interpretation. It collects the electromagnetic radiation information of the earth's surface targets from remote sensing devices on the platforms of satellites and airplanes. Remote sensing for coal geology analyzes the electromagnetic wave spectral traits of landform, stratum lithology and vegetation in coal bearing areas to mark general research directions and relevant topics. In the early stage, remote sensing technology was only used as an auxiliary method to carry out regional geological structure and coal bearing strata distribution survey (Ci et al. 2011; Srivastava 1997; Wang et al. 2002). Based on the study of spectral characteristics of coal seam and rock layer in the ground light field and heat field, a zonation model of coal seam thermal infrared radiation on Sunday was established, and the theoretical basis of coal remote sensing was determined (Zhang et al. 2006). The successful application of remote sensing technology in coal geological mapping, structural analysis, disaster assessment in coal mining area and ecological environment investigation in mining area has greatly improved the efficiency of geological survey in coal mining area, showing the natural advancement of Remote Sensing Application Technology (He and Zeng 2013; Srivastava 1997; Gao et al. 2016; Jin 2019; Li 2013, 2017; Wang 2017; Zhang et al. 2018). At present, a professional technical team of coal remote sensing represented by ARSC has been formed (Lu et al. 2000), which has developed into a specialized remote sensing organization integrating field geological data collection, remote sensing data processing and GIS Development (Wang 2017).

\subsection{Theoretical basis}

Remote sensing coal exploration is based on the coal remote sensing theory, guided by the metallogenic theory, using remote sensing methods to study the coal indicators, coal control factors and coal field distribution patterns, from which, we can extract the coal deposit occurrence information (Tan et al. 2012; Yao 2016). Coal bearing strata are dark gray in remote sensing image, with low reflectivity. However, the reflectivity of the coal seam is lower than 5\%-30\% of surrounding rocks, with unique spectral curve characteristics (Fig. 1). The exposed coal seam and coal bearing strata appear in a special deep tone and layered texture under visible light. In daytime, the thermal infrared image shows high thermal anomaly, while during the night, the thermal infrared image shows low thermal anomaly. Mudstone, shale and sandstone in coal measures of the vegetation covered area are prone to pressure, damage, weathering and erosion due to their weak mechanical strength, which is conducive to the development of vegetation. Therefore, vegetation and geomorphic morphology on remote sensing images can be an important indirect indicator for coal exploration (Tan et al. 2012).

\section{The development history of remote sensing technology}

Since 1965, ARSC has promoted continuous development of coal remote sensing technology and formed the theory and application foundation of coal remote sensing

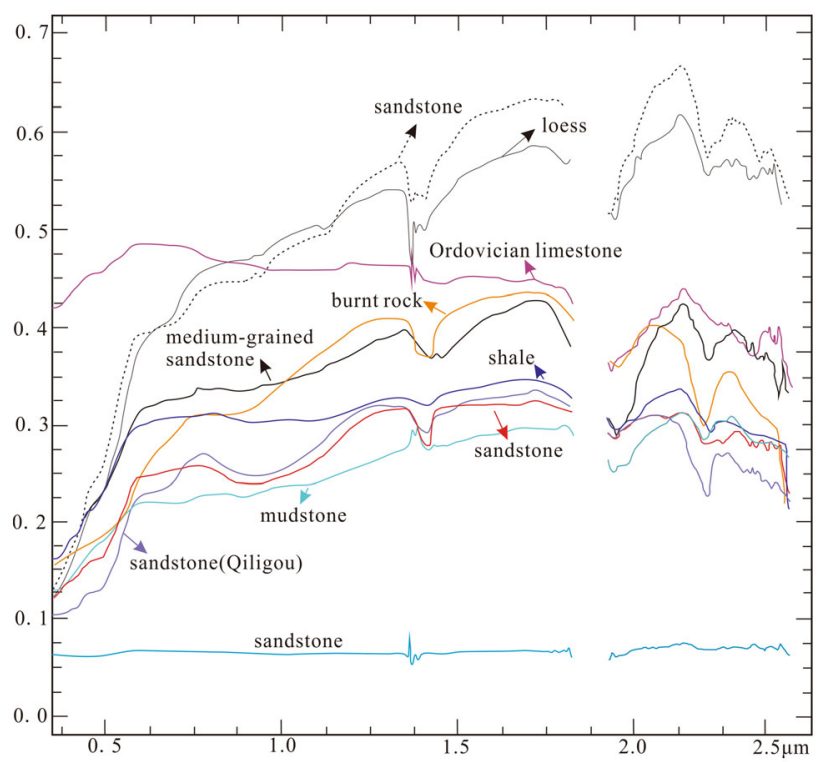

Fig. 1 Spectral curve of common rocks in coal bearing strata 
technology in China. The development process can be divided into five stages: aero-geological mapping, coal remote sensing theory experimental research, application research and promotion, architecture planning and productionisation, and " $3 \mathrm{~S}$ " technology integration and application. Many of the results of projects undertaken by the ARSC have received national and provincial Science and Technology Awards (Table 1).

\subsection{Aero-geological mapping (1965-1981)}

Coal remote sensing technology started from aero-geological mapping in 1960s (Jin 2019; Yan 2017). Aero-geological measurements was a new type of geological mapping method which combines the conventional geological mapping method with the coal field geological information identification method in the aerial photos, utilizing the aerial photogrammetry technology. In July 1966, the aerial measurement team of ARSC and the No. 156 coalfield geological exploration team of Xinjiang completed the geological mapping of nearly $200 \mathrm{~km}^{2}$ (1: 10000) in half a month, by referencing the method of aerial measurement and fulfilling geological mapping. This is the first time that geological mapping has been obtained by aerial measurements in China. After that, ARSC carried out a series of theoretical and technical research in Xinjiang, Shaanxi, Sichuan and other places. By 1969, it had formed a systematic set of aero-geological survey approaches, which were quickly adopted and applied in China. In January 1977, ARSC established an aviation geological team, formulated productionisation and technical management protocols, set delivering quotas and quality standards, and achieved scalable production. By 1988, aviation geological measurements business of ARSC spread across 18 provinces in China, and the large-scale aviation geological measurements regulations were compiled and published. In the mid-1980s, with the rise of space remote sensing technology, aerial geological mapping was gradually replaced by space remote sensing geological mapping, and the aerial geology team of ARSC transformed into the geological remote sensing team.

\subsection{Coal remote sensing theory experimental research (1981-1986)}

In the mid-1970s, the remote sensing geological team of ARSC has undertaken the project of "comprehensive test and research on aerial remote sensing of Xishan coalfield in Taiyuan, Shanxi Province" of the Ministry of Coal Industry, the project of "Application Research on Remote Sensing Technology in the general survey of coalfield in the middle section of the west slope of Daxinganling Mountains (Great Khingan Mountains)" of the National Science and Technology Commission, and the project of "Application Research on Remote Sensing Technology in the hydrogeology of the five mines in the east of Kailuan" of the disaster relief office of the Ministry of Coal Industry. During these projects, a large number of experimental studies have been carried out in coal bearing strata, coal resource prediction and coal mine water disaster control by using space and air remote sensing technology. The patterns of reflection and radiation of coal bearing strata to reflect light and thermal infrared radiation temperature were found, and the basic theory of coal remote sensing was established. The interpretation marks of coal bearing strata, coal seams, folds, fault structures and water rich structures are established, and the methods of remote sensing general survey and coal exploration in grassland covered areas are summarized, forming the methods of remote sensing prediction and coal exploration in coal bearing basins (Guan 1989).

\subsection{Application research and promotion (1987-1996)}

In the middle and late 1980s, coal remote sensing entered a new era of comprehensive development and application. At the beginning of 1987, remote sensing image developed from optical processing to digital processing. The first set of digital image processing system in China's coal industry began to operate in ARSC, which greatly improved the efficiency of remote sensing information extraction and interpretation. Starting 1987, the regional remote sensing geological interpretation (large scale and small scale) using Landsat TM and China land and resources satellite image has been successively used in investigation and prediction of coal resources in Shenmu coalfield in Northern Shaanxi, Datong Coalfield in Shanxi, Xishan coalfield in Shanxi, Ordos coalfield, Qinghai Province, Dehong-Baoshan in Yunnan, Tibet and Taiwan. Coal bearing conditions analysis for general screening was implemented with respect to coal bearing basin delineation, coal control structure, hydrogeological division etc. (Tan et al. 2012). Since the end of 1980s, airborne radar images, spot satellite images of France and satellite images of the Soviet Union have been used in coal remote sensing. In 1988-1990, the application test of airborne side view radar was carried out in Mentougou mining area of Beijing. The experiment of 1:50000 remote sensing geological mapping was carried out in the area from Toutunhe to Huangcaogou of Xinjiang by using the Soviet satellite image, and in Pixia-Wuku of Hetian, Xinjiang by using Spot and TM satellite image. 
Table 1 Main science and technology awards obtained by ARSC in coal remote sensing technology

\begin{tabular}{ll}
\hline No. & Project name \\
\hline 1 & Promotion and application of aero-geological mapping \\
2 & $\begin{array}{r}\text { Application of remote sensing technology in geological } \\
\text { work of xishan coal field in Taiyuan and Great Khingan }\end{array}$
\end{tabular}

3 Research on remote sensing application of land and resources in Shaaxi province

4 Remote sensing geological survey of eastern area in Northern China

5 Environmental remote sensing in Datong mining area

6 Monitoring of spontaneous combustion environment in coal fields in Northern China

7 Evaluation of coal resources and law of coal accumulation in Ordos Basin

8 Investigation on environmental impact and development of high-sulfur coal resources in Sichuan Province

9 Comprehensive survey of remote sensing geology in Tarim Basin

10 Remote sensing hydrogeological research on water supply survey in Shengli open mining area, Xilinhot, Inner Mongolia autonomous region

11 Environmental remote sensing survey of Shenfu Dongsheng coal field

12 Archaeological remote sensing and geophysical integrated detection technology

13 Research on hyperspectral remote sensing of archaeology

14 Research on detection of coal fire and key technology of monitoring in Northern China

15 Theory of comprehensive exploration and new technological system of coal geology in China

16 Key technology of comprehensive survey and engineering application on coal geology in China

17 Research on the national technical guidelines for the field verification of mining rights

18 Verification of data collection on mining rights and development of information system in China

19 Geological report of jurassic coal resources at Longxian, Shaanxi province

20 Remote sensing on emergency investigation and comprehensive study on the secondary geological hazards in Wenchuan earthquake zone

Awarding organization Reward level

Award

year

Ministry of Coal Industry

1st Prize for Scientific Progress

1983

Ministry of Coal Industry

1st Prize for Scientific and

1986

State Scientific and

Technological

Commission

Shaanxi Provincial

Government

Ministry of Coal Industry

Ministry of Coal Industry

Ministry of Coal Industry

Ministry of Science and Technology of China

Ministry of Science and Technology of China

Sichuan Provincial Government

National Development Planning Commission

National Bureau of Coal Industry

National Bureau of Coal Industry

Shaanxi Provincial Government

Shaanxi Provincial Government

Coal Association of China

Coal Association of China

Ministry of Science and Technology of the People's Republic of China

Ministry of Land and Resources

National Bureau of Surveying and Mapping

Coal Association of China

Ministry of Land and Resources
Technological Progress

3rd Prize of National Science and 1987 Technology Progress

1st Prize for Scientific and Technological Progress

3rd Prize for Scientific and Technological Progress

1st Prize for Scientific and Technological Progress

1st Prize for Scientific and Technological Progress

3rd Prize of National Science and Technology Progress

2nd Prize of National Science and 1997

Technology Progress

2nd Prize of Science and

Technology Progress

2nd Prize of the State Planning Commission for Science and

Technology Progress

3rd Prize of Science and

Technology Progress

3rd Prize of Science and

Technology Progress

2nd Prize of Science and Technology Progress

3rd Prize of Science and Technology Progress

1st Prize of Science and Technology Progress

1st Prize of Science and Technology Progress

1998

1998

2nd Prize of National Science and 2010

Technology Progress

2nd Prize of Science and Technology Progress

1st Prize of Science and Technology Progress

Award of Newly Discovered Mineral Resources

1st Prize of Science and

Technology Progress
2000

2004

2007

2007

2011

2012
Based on the exploration of coal remote sensing theory, technology method and application research, coal aviation remote sensing technology has gradually developed into production and application, and the work range has expanded to mineral resources, coal fire disaster, hydrogeology, engineering geology, ecological environment, archaeology and other work (Ding and Sheng 1996; Tan et al. 1998, 1999; Tan 2000). 


\subsection{Architecture planning and productionisation (1997-2012)}

In the late 1990s, many creative studies have been undertaken in the fields of satellite sensor technology, image processing technology, global positioning system and geographic information system, coal remote sensing has carried out a lot of innovative application research in hyperspectral, high-resolution, radar remote sensing, combination of remote sensing and GIS, combination of remote sensing and geophysical exploration, geochemical exploration, drilling and other comprehensive exploration technologies. Complete coal remote sensing technology system has been established, and the development and application of a large number of new technologies have greatly promoted the industrialization and scale development of coal remote sensing. In December 2003, the Ministry of Science and Technology of China approved ARSC to build " $3 \mathrm{~S}$ spatial information industrialization base in the west of China". In November 2008, the Department of Science and Technology of Shaanxi Province approved the construction of "Geospatial Information Engineering Technology Research Center of Shaanxi" by ARSC. A series of regional geological survey, mineral geological survey and exploration were carried out by a combination of remote sensing, ground survey, drilling and geophysical exploration, and, as a result, the new direction of airborne geophysical remote sensing technology was explored ( $\mathrm{Li}$ et al. 2010). In the investigation of Cenozoic coal resources in the east of Salt Range, Pakistan, the coal bearing strata of Patala formation of Paleocene markerwal group were identified by ARSC, which provided technical support for the exploration of coal resources in the area (Du et al. 2017, 2018).

\section{5 "3S" technology integration and application (after 2013)}

After construction of " $3 \mathrm{~S}$ spatial information industrialization base in the west of China" and "Geospatial Information Engineering Technology Research Center of Shaanxi", ARSC has continuously introduced advanced equipment to develop "3S" technology integrated application and precise service. Since 2013, ARSC has applied InSAR and high-resolution comprehensive remote sensing technology to monitor sedimentation in more than 10 mining areas, including old Datong mining area in Qinghai, Yanghuopan and Yushuwan in Shaanxi, and performed stability monitoring of the Sanxia Dam, exploring a feasible method for early identification of major hidden dangers (Ning et al. 2008; Ge et al. 2019). At present, ARSC is actively promoting the findings to serve the geological disaster monitoring in China. From 2013 to 2015, ARSC completed the "Multi-platform farmland information acquisition technology in arid and semi-arid areas" supported by the Ministry of hydrology. It has successfully built an information acquisition platform integrating hyperspectral, multispectral, true color and thermal infrared remote sensing technology of UAV, formed a precision agriculture remote sensing technology service system, and extended the system to the precision agriculture management of cotton, corn and other crops in Xinjiang. In regards to big data platform construction, "Northwest high-resolution satellite data center" and "smart mine" systems have been established. Through cooperation with National Satellite Center, remote sensing data of different types and resolutions can be developed in the future. Through rapid fusion analysis and information extraction, the foundation for real-time monitoring and application of " $3 \mathrm{~S}$ " technology in various fields is laid.

\section{Core research content of coal remote sensing technology}

\subsection{High resolutions}

ARSC has developed a set of technical methods for mineral resources exploration and multi-objective remote sensing investigation and monitoring by using the comprehensive technology of high-resolution remote sensing, geological survey and drilling (Nie 2007). In 2007, the technical specification for remote sensing coal field geological mapping (MT/T 1043-2007) was formulated and published, which is the coal industry specification for aerospace geological mapping. More than 30 national level coal resources investigation projects have been successively carried out in Yunnan, Tibet, Xinjiang, Gansu, Shaanxi, Inner Mongolia and Qinghai, with a total investigation area of more than $10,000 \mathrm{~km}^{2}$ and a cumulative increase of more than 5 billion tons of coal resources.

\subsection{Hyperspectral remote sensing}

ARSC took the leading effort in applying hyperspectral remote sensing technology to coal fire disaster monitoring, mining area environmental investigation and monitoring, remote sensing archaeology and other fields. The project of "Research on new technology of coal fire detection and monitoring in northern China" undertaken by the Ministry of Science and Technology of China and German government established the quantitative inversion model and the method of hyperspectral remote sensing minerals and temperature field in the fire area of Wuda Mining Area in 
Neimenggu (Inner Mongolia) and Rujigou mining area in Ningxia (Tan et al. 2007). In the process of the National 863 project "archaeological remote sensing and geophysical integrated exploration technology", 4 cultural relics and 13 abnormal points were newly discovered in extraction and studies of hyperspectral remote sensing information of soil composition, vegetation growth and water content (Tan et al. 2006). In the 863 project "Jinjing action plan in the West-Earth observation and research", hyperspectral database of vegetation, soil, coal series and coal mine features in Northern Shaanxi were initiated.

\subsection{Radar remote sensing}

ARSC uses the computing technology of space radar image and multispectral image fusion, multi-phase remote sensing image comparison to carry out the real-time image analysis and rescue work in the disaster area. It provides real-time remote sensing images for disaster geological interpretation and disaster loss accounting in the disaster mitigation work, such as the great flood disaster in the middle and lower reaches of the Yangtze River in 1998, the flood disaster in the Han River Basin in southern Shaanxi in 2003, the "5.12" Wenchuan earthquake in 2008, and the Yushu earthquake in Qinghai in 2010, which provides strong support for the local government's decision-making in disaster mitigation. From 2008 to 2010, the National 863 project "application demonstration research of high efficiency aviation SAR remote sensing application system" undertaken by ARSC broke through the technological process of airborne InSAR system measuring and manufacturing 3D products, forming a number of key technologies such as InSAR image-based mapping method (Fu and Tan 2012). The national standard and energy industry standard of technical specification for airborne InSAR system measurement and production 1:10000-1:50000 3D products (GB/T 32874-2016) have been formulated and published.

\section{4 "3S" technology integration}

From 2003 to 2004, ARSC undertook the national major basic research project "major theoretical basic research on environmental dynamic mechanism in arid and semi-arid areas-spatial data analysis platform for environmental dynamic mechanism research". Multi-period thematic remote sensing information extraction and fusion analysis with conventional data were carried out for the water body range, vegetation coverage, vegetation type, desertification, land usage and trends around the middle and upper reaches of the Huanghe River, Qinghai Lake, Bositeng Lake Basin and Kanas Lake, and a big data analysis system for the study of environmental dynamic mechanism in dry and semi-arid areas was established (Gao et al. 2005). From 2002 to 2006, ARSC undertook the project of "Talimu (Tarim) River Basin water dispatching management system" loaning from National Development and Reform Commission and the World Bank. The "Aviation, Aerospace and Ground" integrated water dispatching system has been established for data collection, database construction, remote sensing monitoring and analysis of ecological environment, water resource analysis, water dispatching decision support, consultation decision and business processing in Talimu (Tarim) River Basin (Tan 2007; Tan et al. 2013; Yan 2008).

\subsection{Comprehensive explorations}

The remote sensing geodetic spatial information system developed by ARSC was widely adopted in coal resource exploration, mineral exploration, coal fire monitoring, water conservancy, digital geological report preparation, and the digital sand table system products are widely used in roads, oil fields, coal fields and mining areas. ARSC had made a lot of achievements in the coal geological survey nationwide using the comprehensive exploration methods of remote sensing, ground investigation, geophysical exploration, drilling, logging and other technologies, forming the key technology of China's coal remote sensing geological comprehensive exploration (Fig. 2).

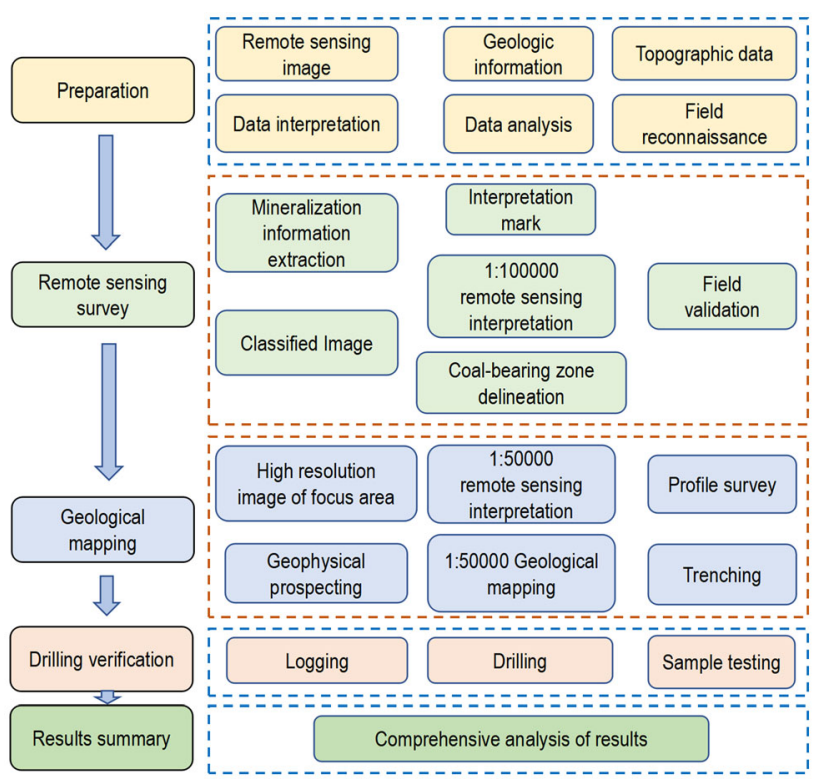

Fig. 2 Stage and key technology of comprehensive coal geology exploration in China 


\section{Development trend and prospect}

\subsection{Development trend}

With the continuous development of high spatial resolution, hyperspectral resolution and high temporal resolution technologies (Van der Meer et al. 2012; Zhang et al. 2014, 2015 ), more and more remote sensing data sources are becoming available, especially remote sensing big data and remote sensing cloud services, which provide powerful impetus for the continuous expansion and deepening of remote sensing application fields (Zhang 2017). With the imaging of spectral information, the multi-polarization of radar imaging, the multi-direction of optical detection, the intellectualization of geoscience analysis, the dynamic of environmental research and the quantification of resource research, the real-time and operation of remote sensing technology will be greatly improved. Remote sensing technology will develop in the direction of multi-scale, multi frequency, all-weather, high-precision, efficient and fast, and in the direction of application system integration, technical method systematization and operation mechanism commercialization. Based on previous research studies, coal remote sensing will accelerate its development in the following directions in the future:

\subsubsection{Big remote sensing data}

With the development of satellite technology, the emergence of new sensors and the rapid development of information technology, the amount of remote sensing data is increasing day by day. It is an inevitable trend to develop new big data preprocessing technology and information extraction technology in a wider range and deeper level, so as to improve the application level of coal remote sensing technology in coal mine safety production monitoring, mining area ground subsidence monitoring, coal mine ecological environment governance and recovery, intelligent mine construction and other aspects (Liang et al. 2007; Ren et al. 2018).

\subsubsection{Integration of remote sensing technology}

Through the integration of multiple scales and types of remote sensing images by GIS, the key technology of coal remote sensing should be used to build a green coal resources survey and evaluation system and a remote sensing system for monitoring and evaluation of coal geological disasters. It is also important to develop business oriented operating systems that adopts coal remote sensing in various coal regions and for different purposes.

\subsubsection{Intelligent assessment of resources and environment}

Hyperspectral lithology identification and hyperspectral mineral mapping technology will be one of the most important high-techs, which supports coal resources and strategic mineral resources investigation, environmental disaster monitoring and Prevention (Gan and Wang 2007; Liu et al. 2006). The development of hyperspectral lithologic identification and mineral mapping in the vegetation covered area has led to continuous innovation in geoscience research technology. The application of hyperspectral remote sensing will be gradually large-scale and intelligent, which improves the accuracy of coal and other mineral investigation, soil quality investigation, land desertification monitoring and mine ecological environment monitoring.

Using hyperspectral remote sensing to carry out the structural research, lithologic mapping, coal resource survey, coal field fire area monitoring and coal mine environment monitoring will become a new field of coal remote sensing.

\subsubsection{Remote sensing data fusion application programming}

Remote sensing data processing methods and models are becoming more and more scientific. The integration of neural network, wavelet, fractal, cognitive model, geoscience experts and image processing system will greatly improve the accuracy and reliability of multi-source remote sensing data fusion, classification and automatic extraction (Shi et al. 2002). The combination of statistical classification, fuzzy technology, expert knowledge and neural network will contribute to the accuracy and number of classification. Multi-platform, multi-spectrum, hyperspectral, multi-angle and multi-level resolution fusion and hybrid applications are an important development direction of remote sensing data processing. Meanwhile, remote sensing data should also be integrated with non-remote sensing data such as geophysical exploration, geological survey, drilling and geochemical exploration and processed by deep mining (Zhu et al. 2014; Wu and Guo 2015).

\subsubsection{Visualization of coal mine management system}

Visualization of Management System in Coal Mine: Establishing the visualization of management system in 3D of underground and upper part, finishing the analysis of measurement in distance, area, excavation calculation, visibility analysis, buffer analysis and flooding analysis, simulating the field exploration, field operation, borehole operation, identification of geological structure, etc. This system provides a new technical platform and a powerful 
tool to evaluate the ore resources, plan the ore deposits, develop designs, manage the decisions and analyze the processes.

\subsubsection{Intelligent coal system}

With the development of remote sensing technology, computer technology, network technology and automation technology, coal informatization is developing to be more integrated, more intelligent and more multi-functional. "Intelligent coal" has become the goal and direction of coal industry informatization. On top of mining information data warehouse, technologies like modern spatial analysis, data mining, knowledge mining, virtual reality, visualization, network, multimedia and scientific computing need to be fully utilized as a new technical platform and powerful toolset for simulation and process analysis of mineral resource evaluation, mine planning, development design, production safety and decision management.

\subsection{Prospect}

Since 2018, the state institutions of China have been greatly reformed and adjusted. The Ministry of Natural Resources, Ministry of Ecological Environment, Ministry of Emergency Management, and Ministry of Agriculture and Rural Affairs were officially established. This is a historical opportunity of this new era, such as the research and market in remote sensing dynamic monitoring of natural resources in mountains, rivers, forests, fields, lakes and grasses, the monitoring and restoration of ecological environment, the monitoring and prevention of disaster emergency, agricultural and rural remote sensing. Equipped with professional advantages, the remote sensing in coal will make great contributions in building a domestic advanced integrated service provider in the application of remote sensing field with extensive geological background.

\section{Compliance with ethical standards}

Conflict of interest The author declared that they have no conflicts of interest to this work. I declare that I do not have any commercial or associative interest that represents a conflict of interest in connection with the work submitted.

Open Access This article is licensed under a Creative Commons Attribution 4.0 International License, which permits use, sharing, adaptation, distribution and reproduction in any medium or format, as long as you give appropriate credit to the original author(s) and the source, provide a link to the Creative Commons licence, and indicate if changes were made. The images or other third party material in this article are included in the article's Creative Commons licence, unless indicated otherwise in a credit line to the material. If material is not included in the article's Creative Commons licence and your intended use is not permitted by statutory regulation or exceeds the permitted use, you will need to obtain permission directly from the copyright holder. To view a copy of this licence, visit http://creativecommons. org/licenses/by/4.0/.

\section{References}

China National Administration of Coal Geology (1993) The first volume of history of coalfield geological exploration in China. Coal Industry Press, Beijing

Ci H, Qin Y, Yang H, Li G, Feng G (2011) Key technology research on remote sensing monitoring of methane emission in coal mine area. Appl Inform Commun 228:70-76

Ding ZJ, Sheng JH (1996) Discussion on remote sensing prospecting model of gold deposits. Henan Geol 14(2):132-138

Du FP, Liu CY, Li CC, Tan FR, Niu JQ, Yang C, Zhao K, Fan Q (2017) Evolution process of the eastern Salt range in the Cenozoic and its response to the phase of the Himalayan movement. Earth Sci Front 24(6):357-368

Du FP, Lv LS, Yang C, Li CC, Tan FR (2018) Characteristics and its evolution of thin-skinned deformation in Eastern Salt Range Pakistan. Geol Sci Technol Inf 37(3):57-64

Fu CY, Tan KL (2012) On interpretation of high-resdution SAR image. Bull Surv Mapp 80(1):42-44

Gan FP, Wang RS (2007) The application of the hyperspectral imaging technique to geological investigation. Remote Sens Land Resour 4(57-60):127-128

Gao HJ, Tan KL, Jiang QG, Huo XB (2005) “3S" technology application to dynamic investigation of sandy desertification land. J Geol Hazards Environ Preserv 16(2):182-185

Gao Y, Li CC, Yin WJ (2016) Application research of remote sensing technology in coalresources survey in southwestern China. Shaanxi Coal 35(6):46-49

Ge DQ, Dai KR, Guo ZC, Li ZH (2019) Early identification of serious geological hazards with integrated remote sensing technologies: thoughts and recommendations. Geom Inf Sci Wuhan Univ 44(7):949-956

Guan HY (1989) Application of remote sensing technology in coal field geology. Acta Geol Sinca 1:36-49

He QS, Zeng FG (2013) Survey and evaluation of coalfield geological exploration and coal resources based on remote sensing technology. Appl Mech Mater 380-384:3930-3933

Hu FR, Li DT (1990) Application of remote sensing technology. Sci Technol Inf Hehai Univ 10(1):86-89

Irvin ME (2002) Remote sensing technology and applications. Opt Eng 41(9):2075

Jin DJ (2019) Aerial remote sensing technology and its applications in geological survey. Remote Sens Land Resour 31(4):1-10

Li SJ (2013) Analysis of coal geological remote sensing technology innovation. Enterp Guide 9:297

Li HJ (2017) Application of remote sensing technology into coal resource investigation and evaluation in Hanyuan area Sichuan province. Miner Eng Res 32(1):55-59

Li Q (2018) The current situation and the contradictory transformation of China's energy security. Int Petrol Econ 26(4):18-26

Li CC, Sun SX, Wang XM, Zhang GC, Niu JQ (2010) Application of remote sensing technology in coal resource investigationand evaluation in Zhaotong Yunnan. Coal Geology China 22(10): 17-21

Liang HY, Gu XF, Tao Y (2007) Analysis of the applications and demands of civil aeronautics remote sensing in coal industry of China. Coal Sci Technol 4:104-107

Liu F, Zhang JX, Jin FX, Shao F, Zhang HT (2005) The original study on the current situation and methods of landmark spectrum. Beijing Surv Mapp 3:1-6 
Liu SW, Gan FP, Yan BK, Yang SM, Wang RS, Wang QH, Tang PK (2006) The application of imaging spectroscopy in the identification and mapping of typical altered minerals. Geol China $1: 178-186$

Lu ZZ, Wang FY, Bao GB (2000) Practice and prospect of satellite remote sensing in coal industry. Geo-Inf Sci 2(2):58-61

Nie HF (2007) Multi target monitoring of remote sensing technology in mineral resources development: Proceedings of 2007 annual meeting of China Association for remote sensing applications. China Association for remote sensing applications, Hanzhong, China, pp 504-509

Nie YP, Yang L (2009) Applications and development of archaeological remote sensing technology in china. J Remote Sens 13(5):940-951

Ning SZ, Wan YQ, Sun SX (2008) A discussion of coal mining area subsidence and remote sensing monitoring. Coal Geol China 20(1):10-12

Ren H, Wu GQ, Ning SZ, Zhu SF, He XL, Liang YP, Wang XJ, Li HL, Geng JJ, Qiao JW (2018) Closed coalmine resources exploitation, utilization and geological indemnification. Coal Geol China 30(6):1-9

Shi YQ, Chen CC, Chen L (2002) Application progress and prospect of remote sensing technology in environmental resources. Remote Sens Land Resour 4:7-13

Srivastava VK (1997) Study of drainage pattern of Jharia coalfield (Bihar) India, through remote sensing technology. J Indian Soc Remote Sens 25(1):41-46

Sun JB (2013) Principles and applications of remote sensing. Wuhan University Press, Wuhan

Tan YT (2000) Disaster and control of spontaneous combustion in coal field, China. Coal Geol Explor 28(6):8-10

Tan KL (2007) Research and development of dynamic monitoring system of ecological environment in Tarim River Basin. Shaanxi Normal University, Xi'an

Tan KL, Lv LS, Zhang DH (1998) Monitoring acide falling pollution by using satellite. Remote Sens Land Resour 10(3):43-45

Tan KL, Wu YZ, Wang FY (1999) Method and practice of water exploration in arid and semi-arid areas by remote sensing technology. Hydrogeol Eng Geology 4:40-43

Tan KL, Wan YQ, Zhou XH, Song D, Duan Q (2006) The application of remote sensing technology in the archaeological study of the Mausoleum of Emperor Qinshihuang. Int J Remote Sens 27(16):3347-3363

Tan KL, Zhou RP, Wan YQ (2007) Remote sensing monitoring method of hyperspectral and high-resolution for underground coal bed combustion. J Infrared Millim Waves 26(5):349-358

Tan KL, Wan YQ, Wang XF, Sun SX, Chen XL (2012) The exploration method of coal resources based on remote sensing technology. Geol China 39(1):218-227

Tan KL, Wang XF, Gao HJ, Cheng WM (2013) Analysis of ecological elements of comprehensive harnessing in Tarim river basin using remote sensing. Geo-Inf Sci 15(4):604-610

Van der Meer FD, Van der Werff HMA, Van Ruitenbeek FJA, Hecker CA, Bakker WH, Noomen MF, Van der Meijde M, Carranza
EJM, De Smeth JB, Woldai T (2012) Multi- and hyperspectral geologic remote sensing: a review. Int J Appl Earth Obs Geoinf 14(1): 128

Wang XX (2007) China's energy security and energy strategic choice. China Sci Technol Forum 1:17-21

Wang XP (2017) Discussion on application of satellite remote sensing technology in coal resource exploration and exploitation. Mine Surv 45(6):31-35

Wang XP, Wu YZ, Chen SJ, Zhou XH, Bai XF (2002) The application of remote sensing technology to coal investigation in Zhongdian area, Yunnan province. Remote Sens Land Resour 14(1):19-22

Wang RS, Xiong SQ, Nie HF, Liang SN, Qi ZR, Yang JZ, Yan BK, Zhao FY, Fan JH, Tong LQ, Lin J, Gan FP, Chen W, Yang SM, Zhang RJ, Ge DQ, Zhang XK, Zhang ZH, Wang PQ, Guo XF, Li L (2011) Remote sensing technology and its application in geological exploration. Acta Geol Sin 81(11):1699-1743

Wu CC, Guo XB (2015) Research on coal exploration technology base upon remote sensing technology in deep area with multilayer coverage taking the surrounding area of Haibowan mine area for example. China Coal 41(4):40-44

Yan ZL (2008) Research on ecological environment dynamic changes and ecological water demand in the Tarim river basin based on RS and GIS. Xi'an University of technology, Xi'an

Yan HP (2017) Application of aerial remote sensing in geological mapping of coal field. Shaanxi Coal 36(5):79-82

Yang SR (1987) Progress in the application of remote sensing technology in China. Environ Remote Sens 1:3-10

Yao YL (2016) Analysis on comprehensive exploration technology system of coal resources in China at present stage. Coal Mine Mach 37(10):1-2

Zhang B (2017) Current situation and future prospects of the development of modern remote sensing technology. J Chin Acad Sci 32(7):774-784

Zhang WR, Kang GF, Wang Y (2006) Application status and Prospect of remote sensing technology in coal geology. Coal Geol China 2:5-8

Zhang CY, Qin QM, Chen L, Wang N, Bai YB, Zhao SS (2014) Hyperspectral remote sensing for coal-bed methane exploration. In: IEEE international geoscience and remote sensing symposium (IGARSS). pp 262-265

Zhang CY, Qin QM, Chen L, Wang N, Zhao SS, Hui J (2015) Rapid determination of coalbed methane exploration target region utilizing hyperspectral remote sensing. Int $\mathrm{J}$ Coal Geol 150:19-34

Zhang YT, Wei CY, Xu YN, Yan J, Huang T, Yang XR, Li QM (2018) An analysis of land use changes and driving forces in Ningdong coal base of Ningxia with remote sensing technology. Geol Bull China 37(12):2169-2175

Zhou GQ (2018) A review of the application of remote sensing technology. Inner Mong Sci Technol Econ 4:86-88

Zhu WP, Xiong SQ, Xue DJ (2014) Aerogeophysical jointly remote sensing detection technology present and prospect. Progress Geophys 29(5):2356-2363 